\title{
Influence of tetrabasic zinc chloride and copper sulphate on growth performance and some physiological parameters in the digestive tract of weanling piglets*
}

\author{
B. Zhang and Y. Guo ${ }^{1}$ \\ State Key Laboratory of Animal Nutrition, College of Animal Science and Technology, \\ China Agricultural University \\ Beijing, 100193, P.R. China
}

(Received 12 June 2008; revised version 20 February 2009; accepted 24 June 2009)

\begin{abstract}
One hundred and sixty weanling piglets with an initial average body weight (BW) of $7.3 \mathrm{~kg}$ were used in a $2 \times 2$ factorial experiment to investigate interactions between tetrabasic zinc chloride (TBZC) and copper sulphate $\left(\mathrm{CuSO}_{4}\right)$ on growth performance. In five piglets per treatment activity of enzymes in pancreas and digesta and short-chain fatty acids (SCFA) concentration in digesta were determined. The piglets were offered the following diets for 28 days: 1 . no supplementation of TBZC and $\mathrm{CuSO}_{4}$; 2. supplementation of $250 \mathrm{mg} / \mathrm{kg} \mathrm{Cu}$ from $\mathrm{CuSO}_{4} ; 3$. supplementation of 1500 $\mathrm{mg} / \mathrm{kg} \mathrm{Zn}$ from TBZC; 4. supplementation of $1500 \mathrm{mg} / \mathrm{kg} \mathrm{Zn}$ from TBZC and $250 \mathrm{mg} / \mathrm{kg} \mathrm{Cu}$ from $\mathrm{CuSO}_{4}$. Each treatment had five replications (pens) of eight piglets (half castrated males and half females). The results showed that average daily gain $(\mathrm{ADG})$ was improved $(\mathrm{P}<0.05)$ by the addition of TBZC and (or) $\mathrm{CuSO}_{4}$. The addition of TBZC increased $(\mathrm{P}<0.05)$ the activity of chymotrypsin in the duodenum contents (3.145 vs 2.095 , respectively). TBZC and $\mathrm{CuSO}_{4}$ synergistically reduced $(\mathrm{P}<0.05) \mathrm{pH}$ of the jejunum contents. The addition of $\mathrm{TBZC}$ or $\mathrm{CuSO}_{4}$ increased $(\mathrm{P}<0.05)$ total SCFA concentrations, and the proportion of acetic acid and propionic acid in the colon. TBZC reduced $(\mathrm{P}<0.05)$ the proportions of isobutyric acid $(1.470$ vs 1.830 , respectively) and isovaleric acid ( 0.171 vs 0.203 , respectively), but $\mathrm{CuSO}_{4}$ increased $(\mathrm{P}<0.01)$ the proportions of isobutyric acid (1.904 vs 1.396, respectively) in the colon. There was a significant interaction between TBZC and $\mathrm{CuSO}_{4}$ for $\mathrm{ADG}(\mathrm{P}<0.01)$, for trypsin activities in both pancreatic tissue homogenates $(\mathrm{P}<0.01)$ and duodenal contents $(\mathrm{P}<0.05)$ and for chymotrypsin activities in both pancreatic tissue homogenate
\end{abstract}

\footnotetext{
* Supported by the National Basic Research Program, Project No. 2004 CB 117504 and by

Scientific Research Fund of China Agricultural University, Project No. 2008029

${ }^{1}$ Corresponding author: e-mail: guoyum@cau.edu.cn
} 
$(\mathrm{P}<0.05)$ and jejunum contents $(\mathrm{P}<0.01)$, and for total SCFA concentrations in the colon. These data indicated that the growth-promotional mechanisms of TBZC and $\mathrm{CuSO}_{4}$ might be different.

KEY WORDS: tetrabasic zinc chloride, copper sulphate, enzymes, SCFA, growth performance, piglets

\section{INTRODUCTION}

Feeding high level of $\mathrm{Zn}$ to weanling piglet could decrease the incidence of non-specific post-weanling scours and improve growth performance (Case and Carlson, 2002; Zhang and Guo, 2007). However, the mechanism of this action is obscure. Our previous experiment indicated that feeding pharmacological tetrabasic Zn chloride (TBZC) improved growth performance of weanling piglets, and that TBZC is a better $\mathrm{Zn}$ source compared with $\mathrm{ZnO}$ for weanling piglet diets to enhance growth performance at lower dosage (Zhang and Guo, 2007).

High dietary concentrations of copper sulphate $\left(\mathrm{CuSO}_{4}\right)$ have long been recognized for its growth-promoting effects in diets for weanling piglets (Bunch et al., 1961; Radecki et al., 1992). Feeding $250 \mathrm{mg} / \mathrm{kg} \mathrm{Cu}$ from $\mathrm{CuSO}_{4}$ improved growth performance of weanling piglets (Armstrong et al., 2004). Previous research indicated that there was an interaction between high level of zinc oxide $(\mathrm{ZnO})$ and $\mathrm{CuSO}_{4}$, but additive responses to growth-promoting were not observed (Smith et al., 1997; Hill et al., 2000). However, recently research reported that organic copper and $\mathrm{ZnO}$ had additive benefits effects on piglet's performance (Pettigrew and Perez-Mendoza, 2007). The additive effects of TBZC and $\mathrm{CuSO}_{4}$ had not been tested.

Weanling of piglets is commonly followed by a depression in growth rate and diarrhoea during first one and (or) two weeks after weaning. Decrease in the activity of digestive enzymes in the pancreatic tissue after weaning has been reported which has been suggested to give a predisposition to the poor growth performance (Hedemann and Jensen, 2004). The $\mathrm{pH}$ in the intestine is an important factor influencing the activity of digestive enzymes. Changes in $\mathrm{pH}$ outside normal ranges can result in decreasing digestive ability and eventually reducing growth performance. In addition, intestinal $\mathrm{pH}$ is also important to keep animal intestinal health by maintaining the balance between nonpathogenic and pathogenic microorganisms. The quantity of short-chain fatty acid (SCFA) produced in the intestine depends on the types and numbers of different bacterial population in the gut (MacFarlane and MacFarlane, 2003). $\mathrm{Cu}$ and $\mathrm{Zn}$ had been recognized as having antibacterial activity (Dupont et al., 1994). Measurement of intestinal responses, such as $\mathrm{pH}$ and SCFA, had been used to determine gut health 
in piglet. It is speculated that supplementing piglet diets with $\mathrm{TBZC}$ and $\mathrm{CuSO}_{4}$ may make an intestinal environment unsuitable for pathogenic bacterial growth.

One objective of this experiment was to evaluate the interactive effects of high concentrations of dietary $\mathrm{Zn}$ as TBZC, and $\mathrm{Cu}$ as $\mathrm{CuSO}_{4}$ on growth performance of weanling piglets. The other objective of this experiment was to further investigate the effect of a growth-stimulating level of TBZC and $\mathrm{CuSO}_{4}$ on the activity of digestive enzymes, intestinal $\mathrm{pH}$ and SCFA concentration of weanling piglets.

\section{MATERIAL AND METHODS}

\section{Animals and diets}

The experiment was designed as a $2 \times 2$ factorial. One hundred and sixty piglets (Landrace $\times$ Large White), weaned at $27 \pm 1$ days of age with an average initial weight of $7.3 \mathrm{~kg}$, were allotted to pens on the basis of similar body weight (BW), ancestry and gender. Each treatment had five replications (pens) of eight piglets (half castrated males and half females). Piglets were housed on hard plastic slotted floors with self-feeders, and automatic stainless nipple waterers. Feed and water were available ad libitum. The basal diets with approximately $138 \mathrm{mg}$ $\mathrm{Zn} / \mathrm{kg}$ and $16 \mathrm{mg} \mathrm{Cu} / \mathrm{kg}$ were formulated to meet or exceed nutrient requirements recommended by NRC (1998). Compositions of the diets and nutrient levels for 1-14 $\mathrm{d}$ or 15-28 $\mathrm{d}$ are shown in Table 1. The four experimental diets were as follows: 1. no supplementation of $\mathrm{TBZC}$ and $\mathrm{CuSO}_{4} ; 2$. supplementation of $250 \mathrm{mg} / \mathrm{kg} \mathrm{Cu}$ from $\mathrm{CuSO}_{4}$; 3. supplementation of $1500 \mathrm{mg} / \mathrm{kg} \mathrm{Zn}$ from TBZC; 4. supplementation of $1500 \mathrm{mg} / \mathrm{kg} \mathrm{Zn}$ from TBZC and $250 \mathrm{mg} / \mathrm{kg} \mathrm{Cu}$ from $\mathrm{CuSO}_{4}$. The tested levels for $\mathrm{Zn}$ and $\mathrm{Cu}$ are outside of the European Union-upper levels ( $\mathrm{Zn}$ : $150 \mathrm{mg} / \mathrm{kg}, \mathrm{Cu}: 170 \mathrm{mg} / \mathrm{kg}$ up to 12 weeks of age). The TBZC $\left[\mathrm{Zn}_{5}(\mathrm{OH})_{8} \mathrm{Cl}_{2} \cdot \mathrm{H}_{2} \mathrm{O}\right]$ contained $58 \mathrm{Zn} \%$. Both the $\mathrm{TBZC}$ and (or) $\mathrm{CuSO}_{4}$ replaced wheat bran in the diet. The experiment lasted 28 days.

Piglets and feeders were weighed for calculation of average daily gain (ADG), average daily feed intake (ADFI) and feed conversion ratio (FCR) on d 14 or d 28 of the experiment. Faecal scores were evaluated daily, and expressed as percentage for a period of two or four weeks. The severity of scours (1-5) based on Zhang and Guo (2007) were assigned daily by a person unaware of the dietary treatments (1 - hard faeces, rarely seen; 2 - no scours, normal consistency of faeces formed; 3 - mild scours, soft, partially formed faeces; 4 - moderate scours, loose, semiliquid faeces; 5-watery faeces). Values of each pen were subsequently averaged for a period of two or four weeks. 
Table 1. Composition of basal diets

\begin{tabular}{|c|c|c|c|c|c|}
\hline \multirow{2}{*}{ Ingredients } & \multicolumn{2}{|c|}{ Amount, \% } & \multicolumn{3}{|c|}{ Calculated composition } \\
\hline & $1-14 \mathrm{~d}$ & $15-28 \mathrm{~d}$ & & $1-14 \mathrm{~d}$ & $15-28 \mathrm{~d}$ \\
\hline Maize & 55 & 55 & $\mathrm{DE}, \mathrm{MJ} / \mathrm{kg}$ & 14.23 & 14.15 \\
\hline Soyabean meal (44\%) & 14 & 14 & $\mathrm{CP}, \%$ & 20.15 & 20.12 \\
\hline Extruded soyabean & 15 & 15 & $\mathrm{Ca}, \%$ & 0.85 & 0.82 \\
\hline Fish meal & 3 & 3 & Total P, \% & 0.634 & 0.7 \\
\hline Sprayed dried plasma proteins & 3 & - & Available P, \% & 0.463 & 0.534 \\
\hline Enzyme-hydrolysate fish powder & - & 3 & \multicolumn{3}{|l|}{ Methionine and } \\
\hline Soyabean oil & 1 & 1 & cystine, $\%$ & 0.731 & 0.716 \\
\hline Whey & 5 & 5 & Lysine, \% & 1.344 & 1.339 \\
\hline Limestone & 0.65 & 0.5 & Threonine, $\%$ & 0.906 & 0.878 \\
\hline Dicalcium phosphate & 1.1 & 1 & \multirow{9}{*}{$\begin{array}{l}\mathrm{Zn}^{2}, \mathrm{mg} / \mathrm{kg} \\
\mathrm{Cu}^{2}, \mathrm{mg} / \mathrm{kg}\end{array}$} & 137.4 & 139.1 \\
\hline Sodium chloride & 0.35 & 0.35 & & 16.2 & 15.5 \\
\hline Colistin $(10 \%)$ & 0.06 & 0.06 & & & \\
\hline Choline chloride $(50 \%)$ & 0.2 & 0.2 & & & \\
\hline L-lysine. $\mathrm{HCl}(78 \%)$ & 0.28 & 0.28 & & & \\
\hline DL-methionine & 0.034 & 0.034 & & & \\
\hline Threonine & 0.04 & 0.04 & & & \\
\hline Vitamin and mineral premix ${ }^{1}$ & 1.0 & 1.0 & & & \\
\hline Wheat bran & 0.286 & 0.536 & & & \\
\hline
\end{tabular}

The use of piglets for this study was approved by the Animal Care Committee of China Agricultural University.

\section{Sample collection}

At the end of the experiment, one barrow that the body weight was near the average of the pen was selected randomly to collect samples. The selected piglets were sacrificed after anaesthetizing by intraperitoneal injection of pentobarbital sodium $(40 \mathrm{mg} / \mathrm{kg}$ ). The abdominal cavity was opened, the pancreas (approximately $10 \mathrm{~g}$ ) was sliced from the same area stored in propylene bags and immediately frozen in liquid nitrogen for further analysis of digestive enzyme activities. On removal of the entire gastrointestinal tract, digesta samples were taken from the duodenum (10 cm from stomach), the jejunum (100 cm from stomach), the ileum $(10 \mathrm{~cm}$ from ileo-caecal orifice) and the proximal colon of each piglet, immediately 
stored in propylene tubes, and frozen in liquid nitrogen immediately. All samples were stored at $-80^{\circ} \mathrm{C}$ until analysis could be performed.

pH measurements

The $\mathrm{pH}$ of the intestinal contents from the duodenum, jejunum, ileum and colon was measured immediately after collection. All $\mathrm{pH}$ measurements were made on a $\mathrm{pH}$ meter, which was standardized with certified $\mathrm{pH} 4$ and $\mathrm{pH} 7$ buffer solutions. The sensitivity of the assay was 0.01 .

\section{Digestive enzyme activity analysis}

The samples were thawed and homogenized $(1: 5 \mathrm{wt} / \mathrm{vol})$ in distilled water at $0^{\circ} \mathrm{C}$, centrifuged at $10000 \mathrm{~g}$ for $10 \mathrm{~min}$ at $4^{\circ} \mathrm{C}$, and the supernatant was used to determine the protein concentration, the activities of trypsin and chymotrypsin. The zymogens of trypsin and chymotrypsin in pancreas homogenates were activated by incubation in $0.1 \%$ enterokinase solution $1: 1$ (vol/vol) for $1 \mathrm{~h}$ at $37^{\circ} \mathrm{C}$.

Trypsin activity was measured from the hydrolysis of $\mathrm{p}$-nitroaniline from benzoyl-DL-arginine-p-nitroanilide (DL-BAPNA) (Gertler and Nitan, 1970). Units were expressed as nanomoles of p-nitroaniline released per min per $g$ of protein. A similar method was used for the determination of chymotrypsin with N-glutaryl-L-phenylalanine-p-nitroanilide (GPNA) replacing BAPNA (Erlanger et al., 1966).

\section{Analysis of the SCFA concentrations}

The concentration of SCFA (acetic acid, propionic acid, isobutyric acid, butyric acid, isovaleric acid, valeric acid) was measured using gas chromatography (Zijlstra et al., 1977). Two hundred mg of chyme were suspended in sterile distilled water $(1.6 \mathrm{ml})$ and metaphosphoric acid $(0.2 \mathrm{ml})$ was added. 2-Mercapto isobutyric acid $(0.2 \mathrm{ml})$ was added as an internal standard. The sample was mixed for $45 \mathrm{~min}$ with an orbital shaker and centrifuged for $15 \mathrm{~min}$ at $10000 \mathrm{~g}$ at room temperature. One $\mu \mathrm{l}$ of the extract were injected onto the column of a Hewlett Packard 19091N-213 series chromatograph with a flame ionization detector, a cross-linked phenyl methyl silicone capillary column $(30 \mathrm{~m} \times 0.32 \mathrm{~mm} \times 0.5 \mu \mathrm{m})$. The carrier gas was helium at $20 \mathrm{ml}$ per min, the air flow was $450 \mathrm{ml}$ per min and the hydrogen flow was $40 \mathrm{ml}$ per min, the injector was heated to $200^{\circ} \mathrm{C}$ and the detector to $250^{\circ} \mathrm{C}$. 


\section{Statistical analysis}

Data were analysed by General Linear Model (GLM) procedure of SAS (2002). The main effects of $\mathrm{TBZC}, \mathrm{CuSO}_{4}$, and their interactions were analysed. At $P$ values $<0.05$, differences were considered as significant. If a significant difference for main effects existed, differences among each treatment group were tested by Duncan's multiple-range test. Each pen served as the experimental unit. Scouring data was analysed after being arcsin transformed. Actual scouring data listed in the table, but SEM was for the transformed data.

\section{RESULTS}

Growth performance. The effect of TBZC and $\mathrm{CuSO}_{4}$ addition on body weight gain and feed consumption was shown in Table 2. The supplementation of TBZC had a clear effect on ADG $(\mathrm{P} \leq 0.05)$ for week 1-2 or week 1-4. The supplementation of TBZC increased ADG of weanling piglets (268 vs 251 for week $1-2,335$ vs 319.5 for week 1-4, respectively). TBZC supplementation did not affect ADG during week 3-4. TBZC did not affect ADFI in any of the periods.

Table 2. Growth performance of weanling piglets fed high dietary concentrations of TBZC or $\mathrm{CuSO}_{4}{ }^{1}$

\begin{tabular}{|c|c|c|c|c|c|c|c|c|c|}
\hline \multirow{2}{*}{ Item } & \multirow{2}{*}{$\begin{array}{l}\mathrm{Zn}, \mathrm{Cu}, \\
\mathrm{mg} / \mathrm{kg}\end{array}$} & \multicolumn{2}{|c|}{0} & \multicolumn{2}{|c|}{1500} & \multirow{2}{*}{ SEM } & \multicolumn{3}{|c|}{ P-value } \\
\hline & & 0 & 250 & 0 & 250 & & $\mathrm{Zn}$ & $\mathrm{Cu}$ & $\mathrm{Zn} \times \mathrm{Cu}$ \\
\hline \multirow{3}{*}{ 1-2 week } & $\mathrm{ADG}, \mathrm{g}$ & $229^{b}$ & $272^{\mathrm{a}}$ & $260^{a}$ & $276^{a}$ & 5.7 & 0.050 & 0.003 & 0.139 \\
\hline & ADFI, g & $377^{b}$ & $407^{\mathrm{ab}}$ & $383^{\mathrm{b}}$ & $435^{\mathrm{a}}$ & 7.3 & 0.137 & 0.002 & 0.373 \\
\hline & FCR & 1.65 & 1.50 & 1.48 & 1.59 & 0.038 & 0.549 & 0.777 & 0.061 \\
\hline \multirow{3}{*}{ 3-4 week } & ADG, $g$ & $352^{\mathrm{b}}$ & $429^{a}$ & $391^{\mathrm{a}}$ & $402^{\mathrm{a}}$ & 8.2 & 0.237 & 0.001 & 0.046 \\
\hline & ADFI, $g$ & $612^{\mathrm{c}}$ & $706^{\mathrm{a}}$ & $624^{\mathrm{bc}}$ & $688^{\mathrm{ab}}$ & 14.0 & 0.953 & 0.004 & 0.582 \\
\hline & FCR & 1.74 & 1.65 & 1.60 & 1.71 & 0.030 & 0.265 & 0.962 & 0.235 \\
\hline \multirow{3}{*}{ 1-4 week } & $\mathrm{ADG}, \mathrm{g}$ & $291^{\mathrm{c}}$ & $348^{\mathrm{a}}$ & $325^{\mathrm{b}}$ & $345^{\mathrm{a}}$ & 5.6 & 0.003 & 0.00 & 0.001 \\
\hline & ADFI, $g$ & $495^{\mathrm{b}}$ & $555^{\mathrm{a}}$ & $503^{\mathrm{b}}$ & $562^{\mathrm{a}}$ & 9.7 & 0.601 & 0.001 & 0.960 \\
\hline & FCR & 1.70 & 1.60 & 1.55 & 1.63 & 0.025 & 0.231 & 0.823 & 0.057 \\
\hline
\end{tabular}

${ }^{1}$ each value represents the mean of five pens of eight pigs $(n=5) ;{ }^{a, b, c}$ means on the same row lacking a common superscript letters are different $(\mathrm{P}<0.05)$; TBZC - tetrabasic zinc chloride; $\mathrm{CuSO}_{4}$ - copper sulphate; ADG - average daily gain; ADFI - average daily feed intake; FCR - feed conversion ratio

The addition of $\mathrm{CuSO}_{4}$ had a clear effect on ADG and ADFI. ADG and ADFI were greater $(\mathrm{P}<0.01)$ in piglets fed diets containing $250 \mathrm{mg} \mathrm{Cu} / \mathrm{kg}$ from $\mathrm{CuSO}_{4}$ in any of the periods. During week 3-4 and week 1-4, an interaction between TBZC and $\mathrm{CuSO}_{4}$ was found for ADG of weanling piglets $(\mathrm{P}=0.001)$. TBZC supplementation stimulated $\mathrm{ADG}$ of piglets fed on diets unsupplemented but not on supplemented 
with $\mathrm{CuSO}_{4}$. During week 1-4, piglets fed diets containing $250 \mathrm{mg} \mathrm{Cu} / \mathrm{kg}$ from $\mathrm{CuSO}_{4}$ or both containing $250 \mathrm{mg} \mathrm{Cu} / \mathrm{kg}$ from $\mathrm{CuSO}_{4}$ and $1500 \mathrm{mg} \mathrm{Zn} / \mathrm{kg}$ from TBZC had the greatest ADG, followed by the animals fed diets containing only TBZC, containing neither TBZC nor $\mathrm{CuSO}_{4}$. None of the dietary treatments affected FCR in any of the periods.

Faecal scores and consistency. The effect of TBZC and $\mathrm{CuSO}_{4}$ on faecal scores and consistency was shown in Table 3 . There were no effect on faecal scores and consistency by supplementation of TBZC and/or $\mathrm{CuSO}_{4}$ in the diets during nursery period.

Table 3. Faecal scores and consistency of weanling piglets fed high dietary concentrations of TBZC or $\mathrm{CuSO}_{4}{ }^{1}$

\begin{tabular}{|c|c|c|c|c|c|c|c|c|c|}
\hline \multirow{2}{*}{ Item } & \multirow{2}{*}{$\frac{\mathrm{Zn}, \mathrm{mg} / \mathrm{kg}}{\mathrm{Cu}, \mathrm{mg} / \mathrm{kg}}$} & \multicolumn{2}{|c|}{0} & \multicolumn{2}{|c|}{1500} & \multirow{2}{*}{ SEM } & \multicolumn{3}{|c|}{ P-value } \\
\hline & & 0 & 250 & 0 & 250 & & $\mathrm{Zn}$ & $\mathrm{Cu}$ & $\mathrm{Zn} \times \mathrm{Cu}$ \\
\hline \multirow{3}{*}{$\begin{array}{l}\text { Faecal } \\
\text { consistency }\end{array}$} & week $1-2$ & 2.12 & 2.12 & 2.04 & 2.12 & 0.0147 & 0.152 & 0.222 & 0.164 \\
\hline & $3-4$ & 2.08 & 2.10 & 2.05 & 2.06 & 0.0180 & 0.340 & 0.616 & 0.851 \\
\hline & $1-4$ & 2.10 & 2.11 & 2.04 & 2.09 & 0.0124 & 0.122 & 0.277 & 0.510 \\
\hline \multirow{3}{*}{$\begin{array}{l}\text { Faecal } \\
\text { scores, } \%^{2}\end{array}$} & $1-2$ & 8.53 & 10.36 & 5.25 & 10.05 & 0.1986 & 0.345 & 0.114 & 0.446 \\
\hline & $3-4$ & 4.43 & 6.65 & 3.10 & 2.87 & 0.1708 & 0.154 & 0.557 & 0.466 \\
\hline & $1-4$ & 6.53 & 8.50 & 4.16 & 6.53 & 0.1524 & 0.156 & 0.161 & 0.893 \\
\hline
\end{tabular}

${ }^{1}$ each value represents the mean of five pens of eight pigs $(\mathrm{n}=5) ;{ }^{2}$ faecal scores (\%) were calculated as the percent of the total number of days when signs of scours were evident within the pen on atal number of days ( $14 \mathrm{~d}$ or $28 \mathrm{~d}$ ); TBZC - tetrabasic zinc chloride; $\mathrm{CuSO}_{4}$ - copper sulphate

$p H$. The effect of TBZC and $\mathrm{CuSO}_{4}$ on intestinal $\mathrm{pH}$ was shown in Table 4. There was only a significant interaction $(\mathrm{P}<0.05)$ between $\mathrm{TBZC}$ and $\mathrm{CuSO}_{4}$ for $\mathrm{pH}$ in the jejunum. The supplementation of $\mathrm{TBZC}$ and $\mathrm{CuSO}_{4}$ reduced $\mathrm{pH}$ in the jejunum compared with the other dietary treatments.

Table 4. Gastrointestinal $\mathrm{pH}$ of weanling piglets fed high dietary concentrations of TBZC or $\mathrm{CuSO}_{4}{ }^{1}$

\begin{tabular}{|c|c|c|c|c|c|c|c|c|}
\hline \multirow{2}{*}{$\begin{array}{l}\mathrm{Zn}, \mathrm{mg} / \mathrm{kg} \\
\mathrm{Cu}, \mathrm{mg} / \mathrm{kg}\end{array}$} & \multicolumn{2}{|c|}{0} & \multicolumn{2}{|c|}{1500} & \multirow{2}{*}{ SEM } & \multicolumn{3}{|c|}{ P-value } \\
\hline & 0 & 250 & 0 & 250 & & $\mathrm{Zn}$ & $\mathrm{Cu}$ & $\mathrm{Zn} \times \mathrm{Cu}$ \\
\hline Duodenum & 5.53 & 5.92 & 5.88 & 5.78 & 0.303 & 0.693 & 0.517 & 0.064 \\
\hline Jejunum & $6.18^{\mathrm{a}}$ & $6.28^{\mathrm{a}}$ & $6.37^{\mathrm{a}}$ & $5.58^{\mathrm{b}}$ & 0.413 & 0.187 & 0.080 & 0.029 \\
\hline Ileum & 6.08 & 6.42 & 6.52 & 6.60 & 0.311 & 0.225 & 0.409 & 0.596 \\
\hline Colon & 6.01 & 6.29 & 6.26 & 6.24 & 0.306 & 0.571 & 0.500 & 0.412 \\
\hline
\end{tabular}

${ }^{1}$ each value represents the mean of five piglets, one pig per pen $(n=5) ;{ }^{a, b}$ means on the same row lacking a common superscript letters are different $(\mathrm{P}<0.05)$; TBZC - tetrabasic zinc chloride; $\mathrm{CuSO}_{4}$ - copper sulphate 
Digestive enzyme activity. The effect of $\mathrm{TBZC}$ and $\mathrm{CuSO}_{4}$ on pancreatic and intestinal digestive enzyme activities was shown in Table 5. There was a significant interaction between $\mathrm{TBZC}$ and $\mathrm{CuSO}_{4}$ for trypsin activities in both

Table 5. Digestive enzyme activities (U/mg protein) in pancreas and in digesta of duodenum, and jejunum of weanling piglets fed high dietary concentrations of TBZC or $\mathrm{CuSO}_{4}{ }^{1}$

\begin{tabular}{|c|c|c|c|c|c|c|c|c|c|}
\hline \multirow{2}{*}{ Item } & \multirow{2}{*}{$\begin{array}{l}\mathrm{Zn}, \mathrm{mg} / \mathrm{kg} \\
\mathrm{Cu}, \mathrm{mg} / \mathrm{kg}\end{array}$} & \multicolumn{2}{|c|}{0} & \multicolumn{2}{|c|}{1500} & \multirow{2}{*}{ SEM } & \multicolumn{3}{|c|}{ P-value } \\
\hline & & 0 & 250 & 0 & 250 & & $\mathrm{Zn}$ & $\mathrm{Cu}$ & $\mathrm{Zn} \times \mathrm{Cu}$ \\
\hline \multirow{2}{*}{ Pancreas } & trypsin & $77.5^{\mathrm{b}}$ & $96.6^{\mathrm{a}}$ & $95.1^{\mathrm{ab}}$ & $78.5^{\mathrm{ab}}$ & 3.35 & 0.967 & 0.833 & 0.007 \\
\hline & chymotrypsin & $3.10^{\mathrm{b}}$ & $4.76^{\mathrm{b}}$ & $8.04^{\mathrm{a}}$ & $5.40^{\mathrm{b}}$ & 0.587 & 0.005 & 0.564 & 0.022 \\
\hline \multirow{2}{*}{ Duodenum } & trypsin & $130.0^{\mathrm{ab}}$ & $146.9^{\mathrm{ab}}$ & $158.0^{\mathrm{a}}$ & $113.6^{b}$ & 6.80 & 0.824 & 0.264 & 0.022 \\
\hline & chymotrypsin & $2.08^{\mathrm{b}}$ & $2.11^{\mathrm{b}}$ & $3.80^{\mathrm{a}}$ & $2.49^{\mathrm{b}}$ & 0.262 & 0.030 & 0.156 & 0.143 \\
\hline \multirow{2}{*}{ Jejunum } & trypsin & 168.6 & 201.7 & 171.4 & 200.2 & 13.59 & 0.982 & 0.307 & 0.941 \\
\hline & chymotrypsin & $1.64^{\mathrm{c}}$ & $2.25^{\mathrm{ab}}$ & $2.79^{\mathrm{a}}$ & $1.86^{\mathrm{bc}}$ & 0.141 & 0.072 & 0.417 & 0.002 \\
\hline
\end{tabular}

${ }^{1}$ each value represents the mean of five piglets, one pig per pen $(n=5) ;{ }^{a, b, c}$ means on the same row lacking a common superscript letters are different $(\mathrm{P}<0.05)$; TBZC - tetrabasic zinc chloride; $\mathrm{CuSO}_{4}$ - copper sulphate

pancreatic tissue homogenates $(\mathrm{P}<0.01)$ and duodenal contents $(\mathrm{P}<0.05)$ and for chymotrypsin activities in both pancreatic tissue homogenates $(\mathrm{P}<0.05)$ and jejunum contents $(\mathrm{P}<0.01)$ at 28 days. $\mathrm{CuSO}_{4}$ supplementation reduced trypsin activities in duodenal contents and chymotrypsin activities in both pancreatic tissue homogenates and jejunum contents of piglets fed on the TBZC diet, but not in those without TBZC. The supplementation of TBZC increased $(\mathrm{P}<0.05)$ chymotrypsin activities in the duodenum contents (3.145 vs 2.095 , respectively). Neither TBZC nor $\mathrm{CuSO}_{4}$ addition had a significant effect on trypsin activities in the jejunum contents.

Short-chain fatty acids. The effect of TBZC and $\mathrm{CuSO}_{4}$ on the SCFA concentrations in the ileum and colon was shown in Table 6. The supplementation of TBZC and $\mathrm{CuSO}_{4}$ had no effect on ileum SCFA concentrations. There was an interaction between TBZC and $\mathrm{CuSO}_{4}(\mathrm{P}<0.05)$ in total SCFA concentrations in the colon. Piglets offered diets containing $250 \mathrm{mg} / \mathrm{kg} \mathrm{Cu}$ from $\mathrm{CuSO}_{4}$ had significantly increased $(\mathrm{P}<0.01)$ total SCFA concentrations in the colon. The piglets offered diets containing TBZC had a significantly higher total SCFA concentrations in the colon than the TBZC-free diets $(\mathrm{P}<0.01)$. TBZC inclusion increased $(\mathrm{P}<0.05)$ the proportion of acetic acid $(15.103$ vs 11.878 , respectively) and propionic acid (6.188 vs 5.059 , respectively), and significantly reduced $(\mathrm{P}<0.05)$ the proportion of isobutyric acid $(1.470$ vs 1.830 , respectively) and isovaleric acid ( 0.171 vs 0.203 , respectively) in the colon. Piglets offered diets supplemented with $\mathrm{CuSO}_{4}$ had significantly increased $(\mathrm{P}<0.01)$ the proportion of acetic acid (14.89 vs 12.09 , respectively), propionic acid (6.625 
vs 4.621, respectively) and isobutyric acid (1.904 vs 1.396 , respectively) in the colon. The supplementation of TBZC and $\mathrm{CuSO}_{4}$ had no effect on colon valeric acid concentration and the ratio of acetic acid to propionic acid.

Table 6. SCFA concentration ( $\mathrm{mg} / \mathrm{g}$ fresh content) in ileum and colon of weanling piglets fed high dietary concentrations of TBZC or $\mathrm{CuSO}_{4}{ }^{1}$

\begin{tabular}{|c|c|c|c|c|c|c|c|c|c|}
\hline \multirow{2}{*}{ Item } & \multirow{2}{*}{$\begin{array}{l}\mathrm{Zn}, \mathrm{mg} / \mathrm{kg} \\
\mathrm{Cu}, \mathrm{mg} / \mathrm{kg}\end{array}$} & \multicolumn{2}{|c|}{0} & \multicolumn{2}{|c|}{1500} & \multirow{2}{*}{ SEM } & \multicolumn{3}{|c|}{ P-value } \\
\hline & & 0 & 250 & 0 & 250 & & $\mathrm{Zn}$ & $\mathrm{Cu}$ & $\mathrm{Zn} \times \mathrm{Cu}$ \\
\hline \multirow[t]{8}{*}{ Ileum } & total SCFA ${ }^{2}$ & 3.197 & 3.212 & 3.498 & 3.595 & 0.258 & 0.572 & 0.885 & 0.976 \\
\hline & acetic acid & 1.965 & 2.090 & 2.193 & 2.247 & 0.138 & 0.494 & 0.749 & 0.899 \\
\hline & propionic acid & 0.947 & 0.934 & 0.979 & 0.990 & 0.090 & 0.812 & 0.998 & 0.947 \\
\hline & isobutyric acid & ND & ND & ND & ND & & & & \\
\hline & butyric acid & 0.236 & 0.180 & 0.266 & 0.281 & 0.034 & 0.356 & 0.771 & 0.614 \\
\hline & isovaleric acid & 0.049 & 0.053 & 0.041 & 0.052 & 0.003 & 0.420 & 0.191 & 0.526 \\
\hline & valeric acid & ND & ND & ND & ND & & & & \\
\hline & $\begin{array}{l}\text { acetic : propionic } \\
\text { acid ratio }\end{array}$ & 2.184 & 2.396 & 2.329 & 2.305 & 0.089 & 0.886 & 0.607 & 0.519 \\
\hline \multirow[t]{8}{*}{ Colon } & total SCFA & $17.166^{c}$ & $24.629^{\mathrm{ab}}$ & $23.265^{b}$ & $26.493^{\mathrm{a}}$ & 0.481 & 0.001 & $<0.001$ & 0.043 \\
\hline & acetic acid & $9.789^{b}$ & $13.966^{\mathrm{a}}$ & $14.390^{\mathrm{a}}$ & $15.815^{\mathrm{a}}$ & 0.455 & 0.003 & 0.007 & 0.150 \\
\hline & propionic acid & $3.723^{b}$ & $6.394^{\mathrm{a}}$ & $5.519^{\mathrm{a}}$ & $6.856^{\mathrm{a}}$ & 0.236 & 0.029 & 0.001 & 0.177 \\
\hline & isobutyric acid & $1.571^{\mathrm{bc}}$ & $2.090^{\mathrm{a}}$ & $1.222^{\mathrm{c}}$ & $1.719^{\mathrm{ab}}$ & 0.068 & 0.018 & 0.002 & 0.936 \\
\hline & butyric acid & 1.564 & 1.659 & 1.641 & 1.607 & 0.072 & 0.935 & 0.832 & 0.659 \\
\hline & isovaleric acid & $0.210^{\mathrm{a}}$ & $0.196^{\mathrm{ab}}$ & $0.156^{\mathrm{b}}$ & $0.187^{\mathrm{ab}}$ & 0.007 & 0.035 & 0.553 & 0.117 \\
\hline & valeric acid & 0.309 & 0.323 & 0.337 & 0.309 & 0.024 & 0.884 & 0.890 & 0.673 \\
\hline & $\begin{array}{l}\text { acetic : propionic } \\
\text { acid ratio }\end{array}$ & 2.657 & 2.223 & 2.601 & 2.471 & 0.118 & 0.692 & 0.251 & 0.530 \\
\hline
\end{tabular}

${ }^{1}$ each value represents the mean of five piglets, one pig per pen $(n=5) ;{ }^{2}$ total SCFA - acetic acid + propionic acid + isobutyric acid + butyric acid + isovaleric acid; + valeric acid; ${ }^{3} \mathrm{ND}$ - not detected a,b,c means on the same row lacking a common superscript letters are different $(\mathrm{P}<0.05)$;

TBZC - tetrabasic zinc chloride; $\mathrm{CuSO}_{4}$ - copper sulphate; SCFA - short-chain fatty acid

\section{DISCUSSION}

Results from the current experiment indicated that supplementation of TBZC increased ADG. This result was consistent with previous reports that supplementation of $\mathrm{Zn}$ at $1500 \mathrm{mg} / \mathrm{kg}$ diet from TBZC enhanced the growth performance of weanling piglets (Mavromichalis et al., 2001; Zhang and Guo, 2007). $\mathrm{CuSO}_{4}$ is commonly added into weanling piglets diets at concentrations above the nutritional requirement, because high level of $\mathrm{CuSO}_{4}$ had been shown to have growth stimulatory properties for weanling piglets (Armstrong et al., 2004). Results similar to these in our experiment, which inclusion of $\mathrm{CuSO}_{4}$ to weanling 
piglet diets increased ADG, were also observed. Limited study is available to document or explain the interactions between TBZC and $\mathrm{CuSO}_{4}$ in weanling piglets. Smith et al. (1997) found an interaction between $\mathrm{ZnO}$ and $\mathrm{CuSO}_{4}$ for $\mathrm{ADG}$ from d 14 to 28 after weaning. A regional study conducted by Hill et al. (2000) found an interaction between $\mathrm{Zn}(\mathrm{ZnO})$ and $\mathrm{Cu}\left(\mathrm{CuSO}_{4}\right)$ for growth performance, and responses to $\mathrm{Zn}$ and $\mathrm{Cu}$ were independent and not additive in the current experiment. There was only an interaction between $\mathrm{TBZC}$ and $\mathrm{CuSO}_{4}$ for 1-4 week ADG. This small difference may be attributed to physical characteristics of $\mathrm{Zn}$ sources ( $\mathrm{ZnO}$ or TBZC). Zhang and Guo (2007) reported that TBZC was completely soluble in $0.4 \% \mathrm{HCl}, 2 \%$ citric acid and neutral ammonium citrate, but the solubility value of $\mathrm{ZnO}$ was 94,70 and $61 \%$ in $0.4 \% \mathrm{HCl}, 2 \%$ citric acid and neutral ammonium citrate, respectively.

Dupont et al. (1994) reported that the inclusion of $\mathrm{Zn}$ or $\mathrm{Cu}$ to cell culture could inhibit the activity of haemolysin from Serpulina hyodysenteriae, an important virulence factor in the pathogenesis of pig dysentery. Previous research reported that high levels of dietary $\mathrm{Zn}$ reduced the incidence and severity of diarrhoea, and improved faecal consistency after weanling (Schell and Kornegay, 1996; Hill et al., 2000). Recently, Zhang and Guo (2007) reported that the faecal scores and consistency were reduced in weanling piglets fed high level of TBZC. Hill et al. (2000) found a significant $\mathrm{Zn}$ and $\mathrm{Cu}$ effects and a $\mathrm{Zn} \times \mathrm{Cu}$ interaction on faecal consistency. They reported that high $\mathrm{Zn}$, high $\mathrm{Cu}$, or the combination of high $\mathrm{Zn}$ and $\mathrm{Cu}$ resulted in firmer stools than in piglets fed only adequate $\mathrm{Zn}$ and $\mathrm{Cu}$. The lack of a reduction in incidence and severity of diarrhoea for TBZC or $\mathrm{CuSO}_{4}$ in this experiment may be explained by the diet composition, and by the excellent health status of the weanling piglets fed the control diet.

Maintenance of optimal $\mathrm{pH}$ in the intestine is necessary for optimal digestive enzyme functionality. In the current study, results showed that neither TBZC nor $\mathrm{CuSO}_{4}$ had significant effects on the $\mathrm{pH}$ of duodenum, ileum and colon contents. However, there was a significant interaction between $\mathrm{TBZC}$ and $\mathrm{CuSO}_{4}$ for $\mathrm{pH}$ in the jejunum contents. TBZC and $\mathrm{CuSO}_{4}$ synergically reduced $\mathrm{pH}$ of the jejunum contents. Feeding high level of $\mathrm{TBZC}$ and $\mathrm{CuSO}_{4}$ resulted in $\mathrm{pH}$ reduction in jejunum, promoted one of the conditions which often associated with an optimal intestine ecosystem (Jensen, 1998). Changes in $\mathrm{HCl}$ secretion by stomach that regulate the $\mathrm{pH}$ may contribute to no effect of TBZC and (or) $\mathrm{CuSO}_{4}$ on $\mathrm{pH}$ of the duodenum contents. Ileal $\mathrm{pH}$ returned to normal ranges more quickly than jejunal $\mathrm{pH}$ when they were perfused with solutions of different $\mathrm{pH}$ (Hurwitz and Bar, 1968) which may explain why TBZC and (or) $\mathrm{CuSO}_{4}$ did not affect the $\mathrm{pH}$ of the ileum contents. In addition, the total SCFA in ileum was not affected by TBZC and $\mathrm{CuSO}_{4}$. The effect of TBZC and $\mathrm{CuSO}_{4}$ on intestinal $\mathrm{pH}$ may warrant further investigation. 
Supplementation of TBZC in weanling piglet diet resulted in marked increases in the activity of chymotrypsin in the pancreatic tissue homogenate and intestinal contents. This result is in agreement with Hedemann et al. (2006) that feeding $2500 \mathrm{mg} / \mathrm{kg} \mathrm{Zn}$ from $\mathrm{ZnO}$ increased the chymotrypsin activity. After weaning, a reduction in the activity of pancreatic enyzmes had been reported (Owsley et al., 1986). The activity of pancreatic digestive enzymes in intestinal contents had been used to evaluate the pancreatic secretion (Hedemann and Jensen, 2004). In this experiment, TBZC stimulated the synthesis and secretion of pancreatic chymotrypsin. This may be associated with the growth-promoting effect of TBZC. The lack of effect of TBZC on the activity of trypsin is contrary to the results obtained in rats where feeding large doses of $\mathrm{ZnO}$ resulted in increasing the activity of trypsin in pancreatic tissue as well as intestinal contents (Szabó et al., 2004). However, Hedemann et al. (2006) reported that the activity of trypsin in pancreatic tissue homogenates but not small intestinal contents was elevated after feeding a high dietary concentration of $\mathrm{ZnO}$. The discrepancy may be attributed to $\mathrm{Zn}$ source and animals used in the experiments. The lack of effect of $\mathrm{CuSO}_{4}$ on the enzyme activities in this experiment is in agreement with previous reports (Luo and Dove, 1996; Hedemann et al., 2006). Surprisingly, the addition of $\mathrm{CuSO}_{4}$ to the diet containing $1500 \mathrm{mg} \mathrm{Zn} / \mathrm{kg}$ TBZC had a negative effect on trypsin activities in duodenal contents and chymotrypsin activities in both pancreatic tissue homogenates and jejunum contents. This result warrants further investigation.

SCFA formation by intestinal bacteria is regulated by environmental, dietary and microbiological factors. The majority of SCFA in the gut are derived from bacterial breakdown of complex carbohydrates as well as proteins and peptides (MacFarlane and MacFarlane, 2003). TBZC and (or) $\mathrm{CuSO}_{4}$ inclusion increased total SCFA concentrations in colon. These augments are mainly due to an increase of acetic and propionic acid concentrations in colon. The lack of effect on the ratio of acetic to propionic acid by TBZC and (or) $\mathrm{CuSO}_{4}$ suggests that the ratio of carbon to nitrogen in colon was not affected by TBZC and (or) $\mathrm{CuSO}_{4}$. The trophic effects of SCFA on epithelial cell proliferation had been documented in vivo studies with rats (Frankel et al., 1994). Campbell et al. (1997) documented that the greater total SCFA production may result in a decrease in mucosal atrophy by normalizing cell proliferation in the mucosa of rats. Dietary incorporation of TBZC and (or) $\mathrm{CuSO}_{4}$, by producing a greater concentration of total SCFA, may be beneficial in improving gastrointestinal health. Increased SCFA production may result in additional energy available for the weanling piglets. Isobutryic and isovaleric acid are formed from amino acid fermentation (MacFarlane and MacFarlane, 2003). In such fermentation, toxic metabolites such as ammonia and amines were formed. TBZC reduced the concentrations of isobutryic and isovaleric acid in colon, and ultimately may improve intestinal health. 


\section{CONCLUSIONS}

In conclusion, supplemented weanling piglet diet with tetrabasic zinc chloride (TBZC) or CuSO4 increased average daily gain during the first 4 week after weaning. The combination of TBZC and $\mathrm{CuSO}_{4}$ did not result in an additive response. It was shown that TBZC stimulated the synthesis and secretion of pancreatic chymotrypsin and may promote intestinal health. This finding may partly explain the beneficial effects of TBZC on growth performance of weanling piglets.

\section{ACKNOWLEDGEMENTS}

We thank Zhong Wang, Jianmin Yuan, Xi He, Yi Wang, Xiaofei Hu, Xiaojun Yang, Jinlei Wen, Xin Yang, Haiying Wang, Zhonghong Hu and Jian Zhao for excellent technical assistance in the experiments.

\section{REFERENCES}

Armstrong T.A., Cook D.R., Ward M.M., Williams C.M., Spears J.W., 2004. Effect of dietary copper source (cupric citrate and cupric sulfate) and concentration on growth performance and fecal copper excretion in weanling pigs. J. Anim. Sci. 82, 1234-1240

Bunch R.J., Speer V.C., Hays V.W., Hawbaker J.H., Catron D.C., 1961. Effects of copper sulfate, copper oxide and chlortetracycline on baby pig performance. J. Anim. Sci. 20, 723-726

Campbell J.M., Fahey Jr. G.C., Wolf B.W., 1997. Selected indigestible oligosaccharides affect large bowel mass, cecal and fecal short-chain fatty acids, $\mathrm{pH}$ and microflora in rats. J. Nutr. 127, 130136

Case C.L., Carlson M.S., 2002. Effect of feeding organic and inorganic sources of additional zinc on growth performance and zinc balance in nursery pigs. J. Anim. Sci. 80, 1917-1924

Dupont D.P., Duhamel G.E., Carlson M.P., Mathiesen M.R., 1994. Effect of divalent cations on hemolysin synthesis by Serpulina (Treponema) hyodysenteriae: inhibition induced by zinc and copper. Vet. Microbiol. 41, 63-73

Erlanger B.F., Edel F., Cooper A.G., 1966. The action of chymotrypsin on two new chromogenic substrates. Arch. Biochem. Biophys. 115, 206-210

Frankel W.L., Zhang W., Singh A., Klurfeld D. M., Don S., Sakata T., Modlin I., Rombeau J.L., 1994. Mediation of the trophic effects of short-chain fatty acids on the rat jejunum and colon. Gastroenterology 106, 375-380

Gertler A., Nitsan Z., 1970. The effect of trypsin inhibitors on pancreatopeptidase E, trypsin, chymotrypsin and amylase in the pancreas and intestinal tract of chicks receiving raw and heated soya-bean diets. Brit. J. Nutr. 24, 893-904

Hedemann M.S., Jensen B.B., 2004. Variations in enzyme activity in stomach and pancreatic tissue and digesta in piglets around weaning. Arch. Anim. Nutr. 58, 47-59

Hedemann M.S., Jensen B.B., Poulsen H.D., 2006. Influence of dietary zinc and copper on digestive enzyme activity and intestinal morphology in weaned pigs. J. Anim. Sci. 84, 3310-3320 
Hill G.M., Cromwell G.L., Crenshaw T.D., Dove C.R., Ewan R.C., Knabe D.A., Lewis A.J., Libal G.W., Mahan D.C., Shurson G.C., Southern L.L., Veum T.L., 2000. Growth promotion effects and plasma changes from feeding high dietary concentrations of zinc and copper to weanling pigs (regional study). J. Anim. Sci. 78, 1010-1016

Hurwitz S., Bar A., 1968. Activity, concentration, and lumen-blood electrochemical potential difference of calcium in the intestine of the laying hen. J. Nutr. 95, 647-654

Jensen B.B., 1998. The impact of feed additives on the microbial ecology of the gut in young pigs. J. Anim. Feed Sci. 7, 45-64

Luo X.G., Dove C.R., 1996. Effect of dietary copper and fat on nutrient utilization, digestive enzyme activities, and tissue mineral levels in weanling pigs. J. Anim. Sci. 74, 1888-1896

MacFarlane S., MacFarlane G.T., 2003. Regulation of short-chain fatty acid production. Proc. Nutr. Soc. $62,67-72$

Mavromichalis I., Webel D.M., Parr E.N., Baker D.H., 2001. Growth-promoting efficacy of pharmacological doses of tetrabasic zinc chloride in diets for nursery pigs. Can. J. Anim. Sci. 81, 387-391

NRC, 1998. Nutrient Requirements of Swine. 10 ${ }^{\text {th }}$ Edition. National Academic Press. Washington, $\mathrm{DC}$

Owsley W.F., Orr Jr. D.E., Tribble L.F., 1986. Effects of age and diet on the development of the pancreas and the synthesis and secretion of pancreatic enzymes in the young pig. J. Anim. Sci. 63, 497-504

Pettigrew J., Perez-Mendoza V., 2007. Organic copper and zinc oxide have additive effects on diets. Nat. Hog Farmer 52, 34-34

Radecki S.V., Ku P.K., Bennink M.R., Yokoyama M.T., Miller E.R., 1992. Effect of dietary copper on intestinal mucosa enzyme activity, morphology, and turnover rates in weanling pigs. J. Anim. Sci. 70, 1424-1431

SAS, 2002. SAS User's Guide: Statistics. Version 9.1. $4^{\text {th }}$ Edition. SAS Institute Inc. Cary, NC

Schell T.C., Kornegay E.T., 1996. Zinc concentration in tissues and performance of weanling pigs fed pharmacological levels of zinc from $\mathrm{ZnO}, \mathrm{Zn}$-methionine, $\mathrm{Zn}$-lysine, or $\mathrm{ZnSO}_{4}$. J. Anim. Sci. 74, 1584-1593

Smith II J.W., Tokach M.D., Goodband R.D., Nelssen J.L., Richert B.T., 1997. Effects of the interrelationship between zinc oxide and copper sulfate on growth performance of early-weaned pigs. J. Anim. Sci. 75, 1861-1866

Szabó J., Hegedus M., Bruckner G., Kósa E., Andrasofszky E., Berta E., 2004. Large doses of zinc oxide increases the activity of hydrolases in rats. J. Nutr. Biochem. 15, 206-209

Zhang B.K., Guo Y.M., 2007. Beneficial effects of tetrabasic zinc chloride for weanling piglets and the bioavailability of zinc in tetrabasic form relative to ZnO. Anim. Feed Sci. Tech. 135, 75-85

Zijlstra J.B., Beukema J., Wolthers B.G., Byrne B.M., Groen A., Dankert J., 1977. Pretreatment methods prior to gas chromatographic analysis of volatile fatty acids from faecal samples. Clin. Chim. Acta 78, 243-250 